\title{
Maize Cultivation in Foothills of Himalayan Shivalik: An Energy Perspective
}

\author{
Rajat Kumar Sharma*, Priyanka Chand, T.K. Bhattacharya, \\ Deepshikha Azad and Akanksha Kumain
}

G.B. Pant University of Agriculture and Technology, India

*Corresponding author

\begin{tabular}{l} 
Ke y w o r d s \\
$\begin{array}{l}\text { Energy, Maize } \\
\text { cultivation, Energy audit, } \\
\text { Input-output Energy, Fuel } \\
\text { Energy, Grain Yield }\end{array}$ \\
\hline Article Info \\
$\begin{array}{l}\text { Accepted: } \\
\text { 23 March } 2018 \\
\text { Available Online: } \\
\text { 10 April } 2018\end{array}$ \\
\hline
\end{tabular}

\section{A B S T R A C T}

This study investigates the energy consumption in maize crop production in the foothills of Himalayan Shivalik range. In this study, 50 farmers were surveyed in Nainital district of Uttarakhand and information related to the production of maize crop production were collected by a predesigned questionnaire. The study revealed that the total energy consumption for animal farm, mixed farm and tractor farm was observed as 7781.82 $\mathrm{MJ} / \mathrm{ha}, 8133.6$ and $8846.6 \mathrm{MJ} / \mathrm{ha}$ respectively in which fertilizer application consumes around $60 \%$ of total energy consumption. Seedbed preparation also consumes significant energy in maize cultivation as it consumes $14-19 \%$ of total energy consumption. Source wise, direct energy sources consume $29-34 \%$ of total energy while indirect sources of energy sources consume $66-71 \%$ of total energy consumption. It also appears from the study that nitrogen fertilizers are the major source of energy. It incurs $60.6 \%$ in animal farms, $64.9 \%$ in mixed farms and $60.12 \%$ in tractor farms respectively. This energy consumption can easily be reduced by applying organic fertilizers. Overall energy productivity in maize crop production was observed as 0.50 to $0.53 \mathrm{~kg} / \mathrm{MJ}$. The energy output to energy input ratio of maize crop production system was observed as 7.34 to 7.84 . The study also revealed that mechanization index for maize crop production is very poor in the region as overall mechanization index was observed only $53 \%$.

\section{Introduction}

Agriculture is a production-oriented sector, requires energy as an important input for crop production. Global food security demands an increase in agriculture production as total cultivable land is decreasing and the population of the world is increasing day by day. In general, various alternatives for increasing agricultural production can be characterized in the form of additional land use, increase yield per unit area and increased cropping intensity. As it is not possible to increase cultivable land for agriculture production, the substantial change in the production may be increased by increasing the use of energy resources. Agricultural economic development is highly correlated with the amount of energy used. Energy is the key input of crop production. Crop yield is affected by the use of energy sources and their magnitude like human power, machines, irrigation, fertilizers, pesticides, diesel etc. Energy is one of the important elements in 
modern agriculture as it heavily depends on fossil and other energy resources. Energy consumption in agriculture has been increasing in response to the limited supply of arable land, increasing population, technological changes, and a desire for higher standards of living (Kizilaslan, 2009). Some studies show that there is a positive relationship between energy usage and productivity. The need to increase food production has resulted in the increased consumption of energy and natural resources because farmers have little knowledge of incentives to use more energy efficient methods (Esengun et al., 2007). The increased use of inputs such as fertilizer, irrigation water, diesel, plant protection chemicals, electricity etc. demands more energy in the form of human, animal and machinery. The commercial energy used in agriculture increased nearly six fold with the growth rate of $11.8 \%$ between $1980-81$ and 2000 , but the share of agriculture in total energy consumption in the country increased from 2.3 to $5.2 \%$ during the same period (Singh et al., 2002). Agriculture is both a producer and consumer of energy. It uses large quantities of locally available non-commercial energy, such as seed, manure and animate energy, as well as commercial energy sources, directly and indirectly, in the form of diesel, electricity, fertilizer, plant protection, chemical, irrigation water, machinery etc. Efficient use of these energy sources helps to achieve increased production and productivity and contributes to the profitability and competitiveness of agriculture sustainability in rural living (Singh et al., 2002). Energy productivity is an important indicator for more efficient use of energy although higher energy productivity does not mean in general, more economic feasibility. The energy input-output analysis is usually made to measure the energy efficiency and environmental aspects. This analysis will determine how efficient the energy is used (Mohammadi et al., 2010).
The forgoing discussion suggests that the increased production requires development and efficient application of energy resources. The efficient use of energy resources depends on the status of agricultural mechanization of the farmer and sources of farm power. Agricultural mechanization and availability of machinery help to perform the agricultural operations timely which increase crop yield as well as cropping intensity. The level of farm power use differs markedly on different categories of farmers depending upon the adoption of modern technology and acquisition of other capital resources. This difference of resources also changes the energy use pattern and efficiency of crop production.

Maize (Zea Mays L.) is the most important cereal crop in India. As per FAO statistics, the average annual production of maize in India comes to about 26.3 MMT, in 2016, against world's average of 875.2 million tonnes over the same period. Thus, India contributes about $3 \%$ to the world maize production. In Uttarakhand, maize is an important crop in Himalayan foothills. The maize is grown in rainy season in maize tomato crop rotation. In Nainital district of Uttarakhand 4,400 ha area is under maize cultivation (Statistical Diary of Uttarakhand 2015).

\section{Materials and Methods}

\section{Data collection}

To assess the situation of energy consumption for maize crop production in Nainital district of Uttarakhand, primary data for energy input resources in crop production year 2017 were collected by field survey and personal interview of farmers. Total 50 farmers of the different category were surveyed in October 2017in Nainital district where 4,400 ha area is under maize cultivation (Statistical Diary of Uttarakhand 2015). The farmers located in 
foothills, as well as hills, were contacted during the course of the survey. Secondary data and energy equivalents for energy input resources and energy output were obtained from the available literature. The data collected for crop production included energy input resources for different farm operations from land preparation up to transportation or to market. Energy inputs via different power sources and material were obtained for each farm operation. These data were collected for each farm through personal interviews of farmers. The farmers were categorized into three categories according to their mechanization status i.e. tractor farms, mixed farms and animal farms. The land holding of farmers contacted during the survey is shown in Table 1.

\section{Estimation of energy inputs}

The working hours of the labour were determined in each operation and pooled to get total human energy. The mechanical energy used on the selected farms included tractor and diesel engines. The mechanical energy was computed on the basis of total fuel consumption $(1 / \mathrm{ha})$ in the different operation.

The energy consumed was calculated using conversion factors $(1$ lit. diesel $=56.31 \mathrm{MJ}$ ) and the same was expressed in MJ/ha. The electrical energy in the study area was used mostly by motors to run the irrigation pump set for water lifting. The consumption pattern of electrical energy was computed using suitable conversion factor and was expressed in MJ/ha (Mittal and Dhawan, 1988). The fertilizer and chemicals were applied in varying quantity depending upon buying capacity of farmers and their preferences. The quantities of different fertilizer and chemicals used on each farm were pooled and total energy for fertilizer and chemical energy were converted into $\mathrm{MJ} / \mathrm{ha}$. Energy is primarily used in agricultural operations for tillage, transportation, irrigation, fertilizer application, spraying, harvesting. Total output energy produced by Kharif maize production was calculated by adding the energy equivalents to fodder as well as maize grains which were obtained by multiplying their quantity per unit area to energy equivalent factors (Table 2). Thus, all the data related to various operations were converted into energy requirement on the unit area basis for both operation wise and source wise. Energy from inputs and outputs were calculated by converting the physical units of inputs and outputs into respective energy units by using appropriate energy equivalents to find out the energy use pattern.

\section{Energy productivity}

Energy productivity is a measure of energy efficiency of crop production system. It is defined as a ratio of crop yield to the total energy input. Energy productivity of wheat crop production system was obtained by the following relationship as proposed by De (2005)

$$
\begin{aligned}
& \begin{array}{l}
\text { Energy } \\
\text { Crop Yield, } \mathrm{kg} / \mathrm{ha}
\end{array} \\
& =\frac{\text { Total Energy Input, MJ/ha }}{\text { (1) }}
\end{aligned}
$$$$
\mathrm{kg} / \mathrm{MJ}
$$

\section{Energy ratio}

Energy ratio of crop production system is the ratio of output energy to the input energy and obtained by the following relationship.

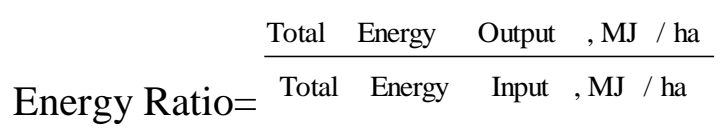

\section{Farm mechanization index}

Mechanization index represents the ratio of work done by machinery to the total work done by human, draft animals and machinery in percentage. Farm mechanization index was calculated by the relationship as proposed by Nowacki (1974). 
$\mathrm{MI}=\frac{\mathrm{LM}}{\mathrm{LT}} \times 100 \%$

Where,

$\mathrm{MI}=$ Mechanization index

$\mathrm{LM}=$ Average sum of all mechanical work of the machine, $\mathrm{MJ} / \mathrm{ha}$

$\mathrm{LT}=\mathrm{LM}+\mathrm{LH}+\mathrm{LA}(4)$

Where,

$\mathrm{LH}=$ Sum of work done by human, MJ/ha

LA = Sum of work done by draft animal, $\mathrm{MJ} / \mathrm{ha}$

\section{Results and Discussion}

\section{Mechanization index}

Energy based mechanization index was calculated and presented in Table 3. Overall mechanization index in maize crop production was observed 53\%. Farmers from all the categories performed sowing, fertilizer application, plant protection, interculture operation manually whereas farmers use tractor or animal power for seed bed preparation and shelling operation. This mechanization gap is observed due to small farm size and poor economic condition of the farmers in the region.

\section{Energy consumption pattern}

The operation wise total energy consumption in maize crop production in Nainital district Uttarakhand is shown in Table 4. The total energy consumption for animal farm, mixed farm and tractor farm was observed as $7781.82 \mathrm{MJ} / \mathrm{ha}, 8133.6$ and 8846.6 MJ/ha respectively. In the comparison of animal and mixed farms, tractor farms were consuming maximum energy. It is due to the fact that tractor farms were consuming more diesel fuel in seedbed preparation to other farms. Also, tractor farms were applying more fertilizer than others. The reason for the differences is the difference in managerial practices and the amount of input consumption. Nevertheless, the difference in the amount of energy input will be less important than the difference in energy productivity and efficiency. But to determine the energy inputs and their share in production is very remarkable.

For example, unlike the results of this experiment, the fertilizer devoted the largest amount of energy consumption to the system, and machinery and diesel fuel were in the next place. Moreover in the study, the amount of consumer energy in both groups of mentioned inputs by Operation wise, fertilizer application consumes more energy followed by seed bed preparation. Since maize crop is grown in rainy season in the reason so the energy requirement in irrigation operation was observed quite low. Fertilizer application is major energy intensive operation which incurred $60 \%$ of total energy consumption. These findings are in conformity with Singh and Singh (1992).

\section{Source wise energy consumption pattern}

The source wise total energy consumption in maize crop production in Nainital district of Uttarakhand is shown in Table 5 and Figure 1. The study suggests that fertilizer is the major source of energy consumption. It incurs 60.6 $\%$ in animal farms, $64.9 \%$ in mixed farms and $60.12 \%$ in tractor farms respectively. Like the results of this study, the studies of Hosseinpanahi and Kafi (2012) and Giampietro et al., (1992) have also demonstrated that nitrogen fertilizer allocated the largest part of energy consumption among chemicals. 
Table.1 Average land holding of farmers contacted during the survey

\begin{tabular}{|l|c|c|l|}
\hline \multicolumn{1}{|c|}{ Category of Farm } & $\begin{array}{c}\text { A verage Land } \\
\text { Holding (ha) }\end{array}$ & $\begin{array}{c}\text { Number of } \\
\text { Farmers }\end{array}$ & \multicolumn{1}{|c|}{ Farm Power Sources } \\
\hline Animal Farm & 0.61 & 11 & Pair of bullocks \\
\hline $\begin{array}{l}\text { Mixed Farm (Animal } \\
\text { + Tractor as a power } \\
\text { source) }\end{array}$ & 1.24 & 15 & $\begin{array}{l}\text { Pair of bullocks + 35 hp } \\
\text { tractor (average hp of tractor } \\
\text { used by farmers in the region) }\end{array}$ \\
\hline \begin{tabular}{l} 
Tractor Farm \\
\hline
\end{tabular} & 2.4 & 24 & $35 \quad$ p tractor \\
\hline
\end{tabular}

Table.2 Energy coefficients for different energy inputs

\begin{tabular}{|c|c|c|c|c|}
\hline Sl. No. & Source & Unit & $\begin{array}{c}\text { Energy equivalent } \\
\text { (MJ) }\end{array}$ & References \\
\hline 1. & Human & Man-hour & $\begin{array}{c}1.961 \text { adult women }= \\
0.8 \text { adult man }\end{array}$ & Mittal and Dhawan 1988 \\
\hline 2. & Animal & Pair-hour & 10.10 & Mittal and Dhawan 1988 \\
\hline 3. & Diesel & Litre & 56.31 & Mittal and Dhawan 1988 \\
\hline 4. & Electricity & $\mathrm{kWh}$ & 16.93 & Mittal and Dhawan 1988 \\
\hline 5. & Seed & $\mathrm{kg}$ & 14.7 & Mittal and Dhawan 1988 \\
\hline 6. & FYM & $\mathrm{kg}$ & 0.3 & \\
\hline \multirow[t]{4}{*}{7.} & Fertilizer & \multirow{4}{*}{$\begin{array}{l}\mathrm{kg} \\
\mathrm{kg} \\
\mathrm{kg}\end{array}$} & & \\
\hline & $\mathrm{N}$ & & 60.6 & Kitani (1999) \\
\hline & $\mathrm{P}$ & & 11.1 & Kitani (1999) \\
\hline & $\mathrm{K}$ & & 6.7 & Kitani (1999) \\
\hline \multirow[t]{2}{*}{8.} & Agro chemical & \multirow{2}{*}{$\begin{array}{l}\mathrm{kg} \\
\mathrm{kg}\end{array}$} & 120 & \\
\hline & Inferior chemicals & & 100 & Kitani (1999) \\
\hline \multirow[t]{4}{*}{9.} & Machinery & \multirow{4}{*}{$\begin{array}{l}\mathrm{kg} \\
\mathrm{kg} \\
\mathrm{kg}\end{array}$} & & \\
\hline & Electric motors & & 64.80 & Mittal and Dhawan 1988 \\
\hline & Prime mover & & 68.40 & Mittal and Dhawan 1988 \\
\hline & Farm machinery & & 62.10 & Mittal and Dhawan 1988 \\
\hline
\end{tabular}

Table.3 Operation wise mechanization index in maize production

\begin{tabular}{|l|}
\hline Operation \\
\hline Seed Bed Preparation \\
\hline Sowing \\
\hline Irrigation \\
\hline Fertilizer Application \\
\hline Plant Protection \\
\hline Interculture Operation \\
\hline Harvesting \\
\hline Shelling \\
\hline Overall \\
\hline
\end{tabular}

\section{Mechanization Index (\%)}

\begin{tabular}{|c|c|}
\hline 77.49 \\
\hline 31 \\
0 \\
0 \\
0 \\
0 \\
\hline 0 \\
\hline 53 \\
\hline 53
\end{tabular}


Table.4 Operation wise energy consumption pattern

\begin{tabular}{l} 
Particulars \\
\hline Seed Bed Preparation (MJ/ha) \\
\hline Sowing (MJ/ha) \\
\hline Irrigation (MJ/ha) \\
\hline Fertilizer Application (MJ/ha) \\
\hline Plant Protection (MJ/ha) \\
\hline Interculture (MJ/ha) \\
\hline Harvesting (MJ/ha) \\
\hline Shelling (MJ/ha) \\
\hline Total Energy (MJ/ha) \\
\hline
\end{tabular}

\begin{tabular}{|c|c|c|}
\hline \multicolumn{3}{|c|}{ Category of Farms } \\
\hline Animal Farm & Mixed Farm & Tractor Farm \\
\hline 1478.40 & 1141.02 & 1490.20 \\
\hline 419.22 & 402.89 & 399.39 \\
\hline 90.79 & 86.75 & 408.05 \\
\hline 4725.76 & 5282.80 & 5323.76 \\
\hline 24.60 & 72.29 & 64.36 \\
\hline 456.00 & 496.73 & 398.86 \\
\hline 196.00 & 196.00 & 196.00 \\
\hline 391.09 & 455.12 & 566.02 \\
\hline $\mathbf{7 7 8 1 . 8 7}$ & $\mathbf{8 1 3 3 . 6 1}$ & $\mathbf{8 8 4 6 . 6 3}$ \\
\hline
\end{tabular}

Table.5 Source wise energy consumption pattern

\begin{tabular}{|c|c|}
\hline \multicolumn{1}{|c}{ Particulars } \\
\hline Human Energy, (MJ/ha) \\
\hline Animal Energy, (MJ/ha) \\
\hline Fuel, (MJ/ha) \\
\hline Electricity, (MJ/ha) \\
\hline Seed, (MJ/ha) \\
\hline Fertilizer, (MJ/ha) \\
\hline Agrochemicals, (MJ/ha) \\
\hline Machinery, (MJ/ha) \\
\hline Total Energy, (MJ/ha) \\
\hline Direct Energy, (MJ/ha) \\
\hline Indirect Energy, (MJ/ha) \\
\hline Yield, t/ha \\
\hline Energy productivity, \\
(kg/MJ) \\
\hline Energy Ratio \\
\hline
\end{tabular}

\begin{tabular}{|c|c|c|}
\hline \multicolumn{3}{|c|}{ Category of Farms } \\
\hline Animal Farm & Mixed Farm & Tractor Farm \\
\hline 1175 & 776.70 & 802.92 \\
\hline 1396.54 & 326.46 & 21.38 \\
\hline 42.18 & 1195.44 & 1769.87 \\
\hline 63.58 & 52.02 & 381.50 \\
\hline 310.33 & 294.00 & 290.50 \\
\hline 4721.41 & 5278.44 & 5319.40 \\
\hline 22.67 & 68.73 & 62.29 \\
\hline 49.21 & 141.82 & 198.78 \\
\hline 7781.87 & 8133.61 & 8846.63 \\
\hline 2678.25 & 2350.62 & 2975.66 \\
\hline 5103.62 & 5782.99 & 5870.97 \\
\hline 4.15 & 4.2 & 4.42 \\
\hline 0.533 & 0.516 & 0.500 \\
\hline & & \\
\hline 7.84 & 7.59 & 7.34 \\
\hline
\end{tabular}

Table.6 Category wise energy productivity and energy ratio

\begin{tabular}{|c|c|c|c|c|}
\hline Category of Farmers & $\begin{array}{c}\text { Total Energy } \\
\text { Input (MJ/ha) }\end{array}$ & $\begin{array}{c}\text { Average } \\
\text { Yield (t/ha) }\end{array}$ & $\begin{array}{c}\text { Energy Productivity } \\
\text { (kg/MJ) }\end{array}$ & $\begin{array}{c}\text { Energy } \\
\text { Ratio }\end{array}$ \\
\hline Animal Farm & 7781.87 & 4.15 & 0.53 & 7.84 \\
\hline Mixed Farm & 8133.61 & 4.2 & 0.52 & 7.59 \\
\hline Tractor Farm & 8846.63 & 4.42 & 0.50 & 7.34 \\
\hline
\end{tabular}


Fig.1 Share of different energy inputs in the production of the maize crop
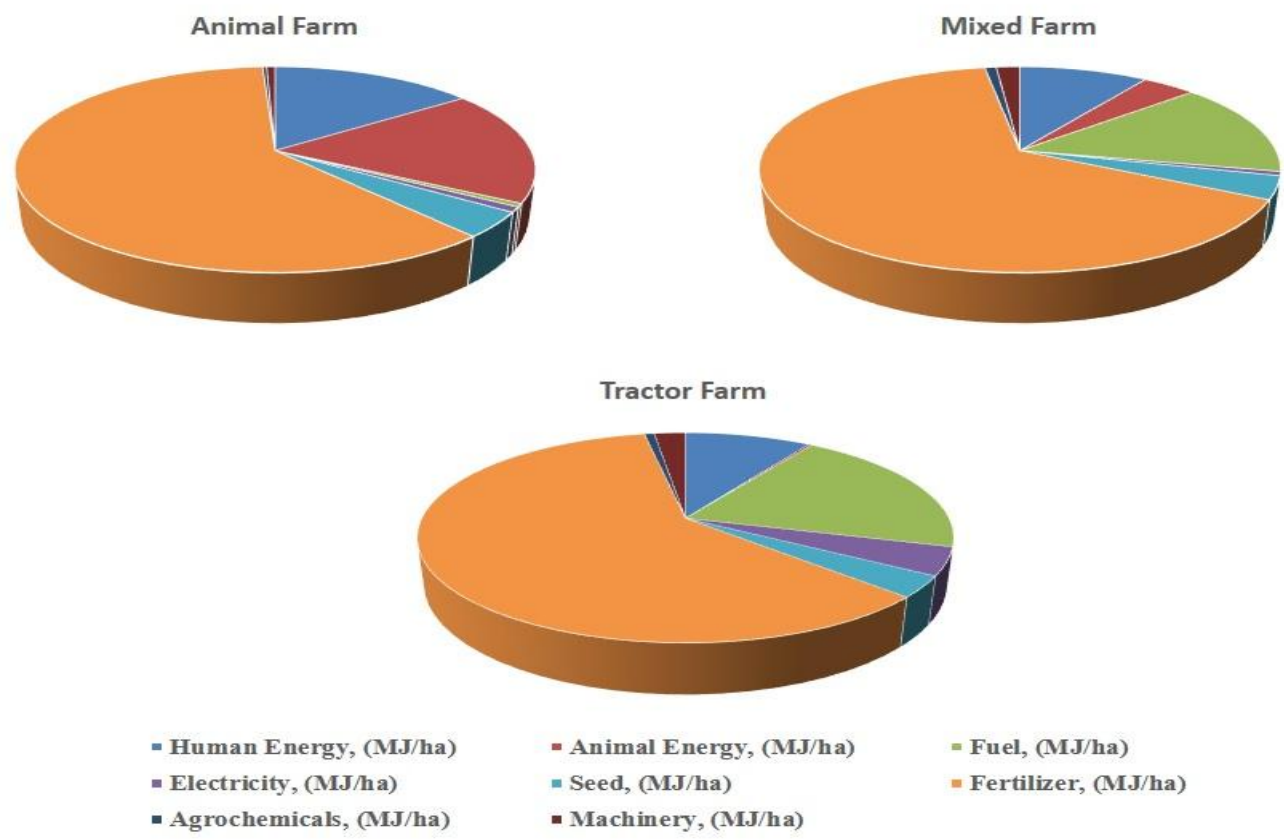

Although nitrogen fertilizer has an effective role in the growth and yield of agricultural plants, it has been always a major source of energy consumption in agriculture. According to the Singh et al., (1998), the amount of energy share by nitrogen fertilizers is about $40 \%$ of the total energy inputs in agricultural production. Also, previous studies on the energy consumption in the fields of maize have shown that nitrogen fertilizer has been the main difference in energy consumption and efficiency of the conventional system versus the sustainable systems in the production of these plants (Pimentel et al., 2005). So considering that the energy consumed to produce Nitrogen, is largely provided by non-renewable sources, a proper solution should be practised for the replacement or lesser use of nitrogen fertilizers. Obviously, animal manures have more effective nutritional effects than chemical fertilizers and also their production requires far less energy consumption so that the consumption of one-ton animal manure has been equal to only $300 \mathrm{MJ}$ (Ozkan et al., 2004) which is equivalent to only $5 \mathrm{~kg}$ nitrogen fertilizer. So the consumption of fertilizers with natural origin helps so much to reduce energy consumption in the production system and increase its productivity. The share of direct energy sources was found 34.4 $\%$ in animal farms, $28.9 \%$ in mixed farms and $33.6 \%$ in tractor farms respectively.

Also, the share of indirect energy sources was observed $65.6 \%$ in animal farms, $71.1 \%$ in mixed farms and $66.4 \%$ in tractor farms respectively. The crop yield was found to be $4.26 \mathrm{t} /$ ha with the observed yield of $4.12,4.2$ and 4.42/ha in animal farms, mixed farms and tractor farms, respectively. It is evident from the study that energy consumption has a positive relationship with crop yield. Higher energy inputs result in higher crop production. These findings are in line with findings of Singh et al., (2007). 


\section{Energy productivity and energy ratio}

Category wise energy productivity and energy ratio in the region is shown in Table 6. One can easily observe from the table that higher energy input results in higher crop yield, however, the energy use efficiency of animal farm is higher than mixed and tractor farm. This implies that animal farms are more energy efficient than tractor farms. This is due to the fact that tractor farms are using diesel fuel for seedbed preparation which is more energy intensive. Also, tractor farms are applying more fertilizer than animal farms.

The study was conducted to ascertain the effects of different energy parameters on maize crop production in the foothills of Himalayan Shivalik. The total energy consumption for animal farm, mixed farm and tractor farm was observed as $7781.82 \mathrm{MJ} / \mathrm{ha}$, 8133.6 and $8846.6 \mathrm{MJ} / \mathrm{ha}$ respectively was observed in maize crop production. The results indicated that fertilizer was the major energy inputs in crop production. However, this energy input did not boost the yield accordingly. In certain cases, the over application of fertilizer has negative effects on crop yield. These results indicated that fertiliser application in maize crop production could be reduced without compromising on the yield. However, Indian farms have the potential to increase the yield by increasing the fertiliser inputs which will boost energy efficiency. In the region, the farmers were heavily dependent on human labour mainly because of the smaller size of the farms.

\section{References}

De, D. 2005. Energy Use in Crop Production System in India. Central Institute of Agricultural Engineering, Bhopal.

Esengun K, Gunduz O, Erdal G. 2007. Inputoutput energy analysis in dry apricot production of Turkey, Energy
Conversion and Management; 48: 5928.

Giampietro, M., Cerretelli, G., Pimentel, D. 1992. Energy analysis of agricultural ecosystem management: human return and sustainability Agricultural and Ecosystems Environment, 38, pp. 219244

Hosseinpanahi, F., Kafi, M. 2012. Assess the energy budget in farm production and productivity of potato. Solanum tuberosum L. in Kurdistan, case study: Plain Dehgolan Journal of Agroecology, 4, pp. 159-169

Kitani O. 1999 Energy and Biomass Engineering. CIGR Handbook of Agricultural Engineering, Vol. V. ST Joseph, MI, USA: ASAE publication

Kizilaslan. H. 2009. Input-output energy analysis of cherries production in Tokat Province of Turkey. Applied Energy 86: 1354-1358.

Mittal, J.P., Dhawan, K.C., 1988. Research manual on energy requirements in the agricultural sector. New Delhi: ICAR; p. $20-33$

Mohammadi, A., Tabatabaeefar. A., Shahin. S., Rafiee. S. and Keyhani. A. 2008. Energy use and economical analysis of potato production in Iran a case study: Ardabil province. Energy Conver. Manage 49: 3566-3570.

Nowacki, T. 1974. Example of Technical Economic Analysis of Mechanized Process in Various Agro-Technical Conditions: Economic Commission for Europe AGRI/MECH/32.

Ozkan, B., Akcaoz, H., Fert, C., 2004. Energy input-output analysis in Turkish agriculture Renewable Energy, 29, pp. 2939-2951

Pimentel, D., Hepperly, P., Hanson, J., Douds, D., Seidel R., 2005. Environmental, energetic, and economic comparisons of organic and 
conventional farming systems Bioscience, 55 pp. 573-582

Singh, H., Mishra, D., Nahar, N. M., 2002. Energy use pattern in production agriculture of a typical village in Arid Zone, India-Part I. Energy Conversion and Management 43.16.:2275-86

Singh, H., Singh, A.K., Kushwaha, H.L., Singh, A., 2007. Energy consumption pattern of wheat production in India. Energy; 32: 1848-54

Singh, S., Singh, G., 1992. Energy input versus crop yield relationship for four major crops of Northern India. AgriMech Asia Africa Latin AM. AMA.; 23.2.: 57-62

Singh, S., Mittal, J.P., Pannu, C.J.S., 1998. Frontier energy use for the cultivation of wheat crop in Punjab. Energy Conversion and Management, 39 pp. 485-491

Uttarakhand, Directorate of Economics and Statistics Planning Department 2014. Statistical Diary of Uttarakhand. pp. 4661 .

\section{How to cite this article:}

Rajat Kumar Sharma, Priyanka Chand, T.K. Bhattacharya, Deepshikha Azad and Akanksha Kumain. 2018. Maize Cultivation in Foothills of Himalayan Shivalik: An Energy Perspective. Int.J.Curr.Microbiol.App.Sci. 7(04): 2961-2969. doi: https://doi.org/10.20546/ijcmas.2018.704.336 